\title{
Muscle Protein
}

National Cancer Institute

\section{Source}

National Cancer Institute. Muscle Protein. NCI Thesaurus. Code C16884.

A special subset of proteins whose roles are directly related to the function of muscle cells. This group is comprised of both short and long filament polypeptides that are primarily involved in movement and muscle contraction and extension. Muscle proteins are also responsible for the conversion of chemical energy into mechanical energy. 